\title{
Glycosylated haemoglobin and plasma glycoprotein assays by affinity chromatography
}

\author{
D. G. Willey, M. A. Rosenthal and S.Caldwell \\ Department of Pathology, Akron General Medical Center, and Isolab, Akron, Ohio, USA
}

\begin{abstract}
Summary. A rapid chromatography method for separating glycosylated protein from non-glycosylated protein, using a boronate-agarose affinity medium which selectively binds the cis-diol groups of glycoproteins, was used to quantitate plasma glycoprotein as well as glycohaemoglobin. The results were found to be independent of: (1) temperature from 16.5 to $29.8^{\circ} \mathrm{C}$; (2) haemoglobin variants, and (3) aldimine glycoprotein adducts. Thus several of the common problems occurring in existing haemoglobin $\mathrm{A}_{1}$ assays are eliminated. There was a close correlation between glycohaemoglobin measured by af-
\end{abstract}

finity chromatography and haemoglobin $\mathrm{A}_{1}$ by cation-exchange $(r=0.959, n=215)$. Specimens from 103 diabetic patients and 112 healthy volunteers were assayed. The following reference ranges were established: glycohaemoglobin $5.5-8.4 \%$; glycosylated total protein $11.5-16.2 \%$; glycoalbu$\min 11.6-19.5 \%$.

Key words: Glycohaemoglobin, plasma glycoprotein, affinity chromatography, diabetes, boronate-agarose resin.
Glycosylated haemoglobin, usually measured as $\mathrm{HbA}_{1}$ or a subfraction of $\mathrm{HbA}_{1}$ (e.g. $\mathrm{HbA}_{1 \mathrm{c}}$ ), has wide acceptance as a long-term index of diabetic control. Limitations of the commonly used mini-column cation-exchange method include temperature dependence [1-4], influence of the results by haemoglobin variants $[1,3,5]$, and interference by the 'labile' aldimine fraction [6] unless appropriate sample preparation steps are taken. Other methods, such as agar gel electrophoresis, suffer from a variety of limitations [7].

We have evaluated an affinity chromatographic method using boronic acid immobilized on an inert agarose medium to measure glycohaemoglobin. This method is specific for glycohaemoglobin [8] and avoids most of the difficulties seen in other procedures.

We also used the affinity method to measure plasma glycoprotein. Some investigators have suggested that plasma glycoprotein values reflect time-averaged blood glucose levels over 3-4 weeks (the protein turnover rate) and therefore indicate intermediate-term diabetic status [9-12].

Method correlations were made with an established commercial $\mathrm{HbA}_{1}$ procedure (Isolab Fast $\mathrm{Hb}$ ). Normal ranges were determined for glycohaemoglobin $(\mathrm{GHb})$, plasma glycosylated total protein, and plasma glycoalbumin determined by affinity chromatography. $\mathrm{GHb}$ and $\mathrm{HbA}_{1}$ are presented as different parameters since affinity $\mathrm{GHb}$ also detects haemoglobin glycosylated at sites other than the $\mathrm{N}$-terminus of the $\beta$ chain.

\section{Materials and methods}

At Akron General Medical Center specimens from 103 diabetic patients and 112 healthy volunteers ( 71 females, 41 males) were assayed for $\mathrm{HbA}_{1}, \mathrm{GHb}$, glycosylated total protein, and glycoalbumin. The healthy volunteers ranged in age from 15 to 82 years. Blood specimens were collected in $5 \mathrm{ml}$ evacuated tubes (Terumo Medical Corporation, Elkton, Maryland, USA) containing EDTA, mixed and delivered to the laboratory on ice, then promptly centrifuged to separate plasma from erythrocytes. Plasma was used for the affinity glycosylated total protein and glycoalbumin procedures. Haemolysates for affinity $\mathrm{GHb}$ were prepared from erythrocytes washed in saline $(0.154 \mathrm{~mol} / \mathrm{l})$.

The affinity columns and associated reagents (Glyc-Affin) were obtained from Isolab, Akron, Ohio, USA, as were cation-exchange mini-columns and reagents used to measure $\mathrm{HbA}_{1}$.

Elution buffer requirements for the affinity method were $2 \mathrm{ml}$ for each fraction. Absorbance measurements on the separated fractions were used to calculate glycoprotein values as a percentage of total protein present. The dye-reagents provided to quantitate affinity glycosylated total protein and glycoalbumin were Coomassie Brilliant Blue G-250 and Bromcresol Green, respectively. The affinity columns were regenerated and used 10 times each.

To assess the effect of temperature on the affinity $\mathrm{GHb}$ measurements, we assayed three different samples representing different $\mathrm{GHb}$ levels at $16.5^{\circ}, 23.0^{\circ}, 26.8^{\circ}$, and $29.8^{\circ} \mathrm{C}$.

To assess the influence of labile $\mathrm{HbA}_{1}$ in the affinity $\mathrm{GHb}$ assay, glucose was added to several whole blood samples to increase the labile $\mathrm{HbA}_{1}$ levels artificially [13]. Affinity $\mathrm{GHb}$ measurements were 
Table 1. Mean values and $95 \%$ confidence limits of assays

\begin{tabular}{llcc}
\hline Method & $\begin{array}{l}\text { Number of } \\
\text { normal } \\
\text { specimens }\end{array}$ & $\begin{array}{l}\text { Mean } \\
\text { value } \\
(\%)\end{array}$ & $\begin{array}{l}\text { Normal range } \\
95 \% \text { confidence } \\
\text { limits }(\%)\end{array}$ \\
\hline Isolab HbA & 112 & 6.4 & $5.3-7.5$ \\
Glyc-Affin haemoglobin & 112 & 6.9 & $5.5-8.4$ \\
Glyc-Affin total protein & 108 & 13.8 & $\mathbf{1 1 . 5 - 1 6 . 2}$ \\
Glyc-Affin albumin & 107 & 15.5 & $\mathbf{1 1 . 6}-19.5$ \\
\hline
\end{tabular}

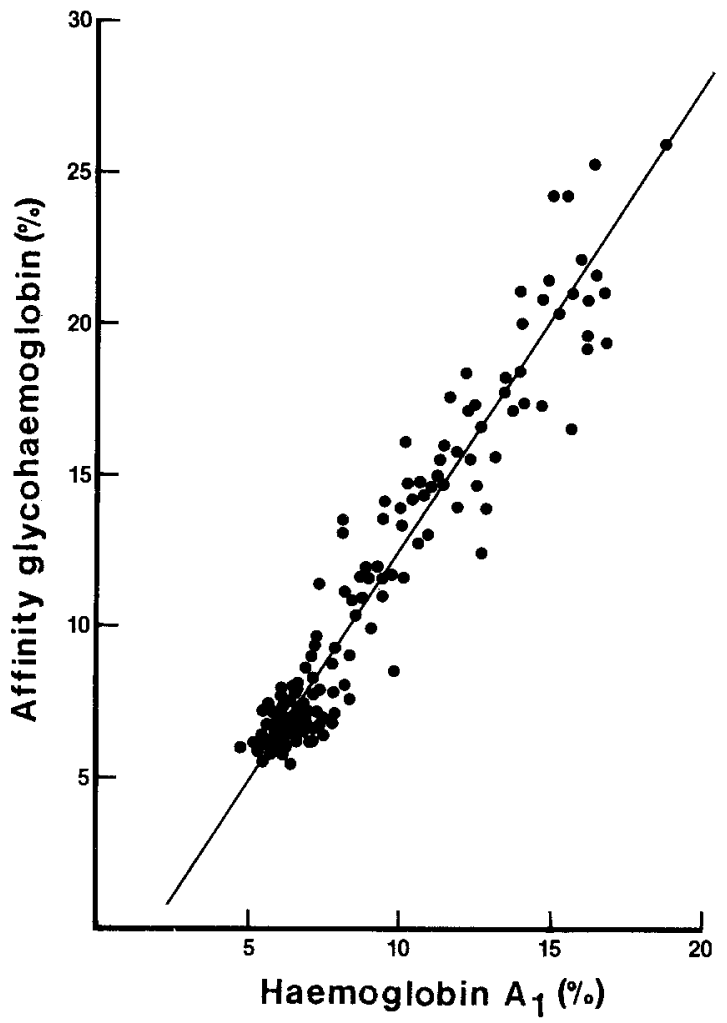

Fig. 1. Correlation between results by the affinity method $(\mathrm{GHb})$ and the cation-exchange method $\left(\mathrm{HbA}_{1}\right)$. [Affinity glycohaemoglobin $(\%)=1.557 \times$ haemoglobin $\left.\mathrm{A}_{1}(\%)-2.955, r=0.959, n=215\right]$

then compared to Isolab $\mathrm{HbA}_{1}$ measurements before and after incubation with saline to remove the labile fraction.

Special studies, including electrophoresis for $\mathrm{HbS}$ and alkali denaturation for $\mathrm{HbF}$, were performed on any haemoglobinopathy specimens encountered to evaluate haemoglobinopathy effects on affinity $\mathrm{GHb}$ measurements.

\section{Results}

Flow rates of at least $0.2 \mathrm{ml} / \mathrm{min}$ gave rapid separation using the affinity columns. Total assay time for affinity $\mathrm{GHb}$ was usually $<1 \mathrm{~h}$. The extra colour development step needed for the plasma glycoprotein fractions added $30 \mathrm{~min}$ to these assay times.

Insignificant variations in affinity $\mathrm{GHb}$ values were seen for normal, elevated, and highly elevated levels measured at temperatures of $16.5^{\circ}-29.8^{\circ} \mathrm{C}$. The range of results for each of the three levels were $5.2-5.6 \%$, $18.2-19.1 \%$, and $47.5-48.0 \%$.
No interference in the affinity $\mathrm{GHb}$ assay due to aldimine adducts was observed. In blood specimens with artificially elevated $\mathrm{HbA}_{1}$, four tubes averaged $\mathrm{GHb}$ at $8.7 \%$ and $\mathrm{HbA}_{1}$ at $29.5 \%$. After these tubes were incubated at $37^{\circ} \mathrm{C}$ for $4 \mathrm{~h}$ to remove the labile fraction, the averages were $(\mathrm{GHb}) 8.7 \%$ and $\left(\mathrm{HbA}_{1}\right) 6.9 \%$.

The manufacturers report within-run and betweenrun coefficients of variation of $<7 \%$ for affinity determinations. In clinical usage over a period of 3 months, we saw coefficients of variation for glycoprotein (erythrocytes and plasma) of $<9 \%$ in a normal volunteer from whom samples were drawn weekly. These higher coefficients of variation include fluctuations of in vivo glycosylation as well as analytical variables. Nevertheless the precision of the affinity procedure is comparable to that of cation-exchange mini-column methods, or better [14].

Normal ranges, calculated as mean $\pm 2 \mathrm{SD}$, are given in Table 1. Histograms showed Gaussian or nearGaussian frequency distributions.

The normal range for affinity $\mathrm{GHb}$ was found to be $5.5-8.4 \%$, showing close agreement with the manufacturer's normal range $(5.5-8.5 \%)$. The plasma glycosylated total protein and glycoalbumin ranges are reasonably close to those reported for glycosylated human albumin by Day et al. $(6 \%-15 \%)[15]$.

A good correlation was seen between $\mathrm{GHb}$ and $\mathrm{HbA}_{1}$ for the combined patient and normal population $(r=0.959$, Fig. 1). A poorer correlation was seen between glycosylated total protein and $\mathrm{HbA}_{1}$ for the combined population $(r=0.808)$. No significant correlation was observed between glycosylated total protein and $\mathrm{HbA}_{1}$ in normal subjects.

A definite advantage in using the affinity method was seen in two specimens from diabetic patients containing $\mathrm{HbS}\left(\mathrm{GHb} 18.5 \%, \mathrm{HbA}_{1} 8.4 \%\right.$ and $\mathrm{GHb} 19.6 \%$, $\mathrm{HbA}_{1} 7.0 \%$ ). The $\mathrm{HbA}_{1}$ values greatly underestimated the glycosylated haemoglobin status of these patients.

One other specimen contained $\mathrm{HbF}$ and gave the following results: $\mathrm{GHb} 6.4 \%, \mathrm{HbA}_{1} 10.3 \%$. The $\mathrm{HbF}$ of this specimen was determined by alkali denaturation to be $4.0 \%$. The falsely elevated result obtained by the cation-exchange method was apparent $[1,3]$.

\section{Discussion}

The good correlation between affinity $\mathrm{GHb}$ and cationexchange $\mathrm{HbA}_{1}$ supports the use of the affinity method in monitoring long-term glycaemic status, similar to the way in which $\mathrm{HbA}_{1}$ is now used. The poor correlation between glycosylated total protein and $\mathrm{HbA}_{1}$ may be due in part to significant individual differences in plasma protein turnover rate. In any case, they reflect glycosylation over different periods of time.

Dolhofer et al. $[9,16]$ have produced data supporting the clinical usefulness of plasma glycoprotein measurements in monitoring the effectiveness of diabetic 
treatment over a relatively short period of time. Plasma glycoprotein levels may also be useful in monitoring gestational diabetes soon after its onset when erythrocytes have not had sufficient time to glycosylate fully. The normal ranges we report should provide useful guidelines.

A major advantage of the affinity $\mathrm{GHb}$ procedure was seen in patients with haemoglobinopathies. Since the affinity method measures the glycosylated form of any variant present, false indications of a patient's glycosylation status are avoided. It would be of interest to examine this effect in patients with other haemoglobin variants.

Analytically we have demonstrated that the affinity technique is relatively rapid, uncomplicated and reliable. The labile component is not measured and the assay can be run at ambient temperature in any laboratory.

\section{References}

1. Simon M, Eissler J (1980) Critical factors in the chromatographic measurement of glycohemoglobin $\left(\mathrm{HbA}_{1}\right)$. Diabetes 29: 267-274

2. Schellekens APM, Sanders GTB, Thornton W, van Groenstein T (1981) Sources of variation in the column-chromatographic determination of glycohemoglobin $\left(\mathrm{HbA}_{1}\right)$. Clin Chem 27:94-99

3. Kaplan LA, Cline D, Gartside P, Burnstein S, Sperling M, Stein EA (1982) Hemoglobin $A_{1}$ in hemolysates from healthy and insulin-dependent diabetic children, as determined with a temperature-controlled mini-column assay. Clin Chem 28: 13-18

4. Rosenthal MA (1979) The effect of temperature on the fast hemoglobin test system. Hemoglobin 3: 215-217

5. Aleyassine H (1979) Low proportions of glycosylated hemoglobin associated with hemoglobin S and hemoglobin C. Clin Chem 25: $1484-1486$
6. Goldstein DE, Peth SB, England JD, Hess RL, DaCosta J (1980) Effects of acute changes in blood glucose on $\mathrm{HbA}_{1 \mathfrak{c}}$. Diabetes 29: 623-629

7. Nathan DM (1981) Labile glycosylated hemoglobin contributes to hemoglobin $\mathrm{A}_{1}$ as measured by liquid chromatography or electrophoresis. Clin Chem 27: 1261-1263

8. Mallia AD, Hermanson GT, Krohn RI, Fujimoto EK, Smith PK (1981) Preparation and use of a boronic acid affinity support for separation and quantitation of glycosylated hemoglobins. Anal Letters (B8): 649-661

9. Dolhofer R, Wieland OH (1980) Increased glycosylation of serum albumin in diabetes mellitus. Diabetes 29:417-422

10. Guthrow CE, Morriw MA, Day JF, Thorpe SR, Baynes JW (1979) Enhanced nonenzymatic glycosylation of human serum albumin in diabetes mellitus. Proc Natl Acad Sci 76: 4258-4261

11. Kennedy AL, Kendell TW, Merimee TJ (1979) Serum proteinbound hexose in diabetes. Diabetes 28: 1006-1010

12. Kennedy AL, Merimee TJ (1981) Glycosylated serum proteins and hemoglobin $A_{1}$ levels to measure control of glycemia. Ann Int Med 95: 56-58

13. Fluckiger R, Winterhalter KH (1976) In vitro synthesis of hemoglobin $A_{1 c}$. FEBS Lett 71: 356-360

14. Hammons GT, Junger J, McDonald JM, Ladenson JH (1982) Evaluation of three minicolumn procedures for measuring hemoglobin $\mathrm{A}_{1}$. Clin Chem 28: 1775-1778

15. Day JF, Thorpe SR, Baynes JW (1979) Nonenzymatically glucosylated albumin. J Biol 254: 595-597

16. Dolhofer R, Renner R, Wieland OH (1981) Different behaviour of haemoglobin $A_{1 a-c}$ and glycosyl-albumin levels during recovery from diabetic ketoacidosis and non-acidotic coma. Diabetologia 21: $211-215$

Received: 31 December 1982

and in revised form: 10 May 1984

Dr. David G. Willey

Accu-Tox Laboratories, Inc.

4900 Frank Avenue, NW

North Canton, OH 44720

USA 